\title{
ЗВУКОВИЙ ДЕКОР ПОЕТИЧНОГО ПРОСТОРУ МИКОЛИ ВІНГРАНОВСЬКОГО
}

Мішеніна Т. М. Звуковий декор поетичного простору Миколи Вінграновського.

У статті зроблено спробу здійснити лінгвостилістичний аналіз звукового тла поетичного простору Миколи Вінграновського. Виокремлено групи звукових комплексів, розкрито особливості їх функціонування.

Ключові слова: звуковий комплекс, перенесення, перцепція.

Мишенина Т. М. Звуковой декор поэтического пространства Николая Винграновского.

В статье сделана попытка лингвостилистического анализа звукового полотна поэтического простора Николая Винграновского. Выделены группы звуковых комплексов, раскрыты особенности их функционирования.

Ключевые слова: звуковой комплекс, перенос, перцепция.

Mishenina T. M. Sound décor space poetry of Nicola Vingranovskiy.

The article is an attempt to linguistic-stylistic analysis of poetic sound fabric of space Nicolas Vingranovskogo. The groups sound systems, disclosed the features of their functioning.

Key words: sound complex, transport, perception. 
Перцепція художніх творів становить надзвичайно складний процес, вимагаючи від поціновувачів мистецтва і високої загальної культури, і великого тезауруса (осмислення нагромаджених знань), i розвиненого естетичного сприймання, i навичок читання тексту, художньої картини. Сприймання художньої літератури й образотворчого мистецтва зобов'язує реципієнта до праці і творчості; читачеві доводиться репродукувати, відтворювати зміст тексту, художньої картини, керуючись орієнтирами, які він віднаходить у них. Кінцевий результат завжди визначається розумовою, емоційною, духовною діяльністю особистості.

Продовжуючи дослідження тексту як мистецького явища i закономірностей його перцепції, зазначимо, що нині у світовій науці немає єдиної концепції сприймання. Роздуми про текст та його сприймання $€$ різними, почасти полярними, обгрунтованими відмінними одна від одної теоріями. Чітких демаркаційних ліній між цими вченнями немає, їм властива онтологічна флюїдність та семантична інтертекстуальність. Текст і його рецепцію досліджували представники психолінгвістичної теорії (О. Потебня); психоаналізу та теорії архетипів (З. Фройд, К. Г. Юнг, Н. Фрай); феноменологічної теорії та критики (М. Гартман, Р. Інгарден, Ж. Рішар); літературної герменевтики (М. Гайдеггер, Г. Гадамер); екзистенціальної моделі в теорії мистецтва (П. Сартр); школи рецептивної естетики (В. Ізер, Г. Яусс); структуралізму і семіотики (К. Леві-Стросс, Р. Якобсон, Р. Барт, У. Еко, Ю. Лотман); постструктуралізму та деконструктивізму (М. Фуко, Ж. Дерріда, П. де Ман) та інші [2; 4; 5].

Деякі науковці переконані, що твори мистецтва не мають визначеного змісту; вони становлять формальні подразники. Змістовний не твір, а викликана, збуджена ним реакція. Такі сентенції провокують висновки, що художня одиниця не має визначених стійких якостей, що ці якості є релятивними (відносними), а той чи інший «читацький» твір не пов’ язаний із тим, що в ньому висловив митець і що в ньому об' єктивно закладено.

Ми дотримуємося думки про те, що сприймання тексту не може бути монологом автора чи монологом читача, а їхнім діалогом. Справжній мистецький твір естетично досвідченого читача завжди вводить у багатомірну просторінь діалогу. Йдеться про розмову 3 автором, розмову з епохою і розмову з собою, зі своїм Я, оскільки під час спілкування із книгою відбувається утвердження свого Я. Діалог 
перетворюється на полілог, який відбувається симультанно в різних напрямках i на різних рівнях емоційного співпереживання прочитаного. Можливість такого широкого і багатоканального діалогу забезпечується, безумовно, особливостями художнього простору, які конденсують реальний час i простір, розширюючи їх до непередбачуваних меж в уяві реципієнта. Між об'єктом (твір літератури) і суб' єктом завжди виявляються реальні стосунки, в яких розкриваються різні аспекти художньої одиниці.

Об'єкт, незалежно від того, які мистецькі аспекти його краще проявляються, завжди $є$ єдністю всіх властивих йому якостей. Iз еволюцією суб'єкта змінюються й реальні кореляції між ним і об'єктом, а отже, і характер осягнення його художніх аспектів. Художній твір є стосовно реципієнта активно дійовим чинником, оскільки у його структурі, як правило, $\epsilon$ наявною програма для організації сприймання. У мистецькому тексті закодовано потенціальну поведінку читача. Починаючи від О. Потебні, літературознавці твердять, що художній твір $є$ спільним витвором письменника і того, хто його сприймає. І. Дзюба, коментуючи роздуми О.Потебні про дію літератури на поціновувача, зазначає: «Відношення між письменником і читачем аналогічне відношенню між тим, хто говорить, і тим, хто слухає. В обох випадках один співчлен не може здобути свого буття без другого» [1].

Мета публікації - виокремити i розкрити семантикофункціональне навантаження звукових комплексів у поезіях Миколи Вінграновського.

Поетичний простір Миколи Вінграновського презентує поліголосся художньої картини. За семантичним навантаженням можна виокремити кілька груп звукових корелятів.

Узагальнене значення орнітоніма, який усвідомлюється як символ, що містить семантичні коди для носіїв української нації «прагнення», «світлоносність», «незрадливість / щирість». Наведені складники семантичного ядра орнітоніма, на наше переконання, засвідчують тенденцію безпосередньо ототожнених станів людини й орнітоніма, сприймання носієм української культури орнітоніма як рівноцінної істоти 3 рівномірним масштабом цінностей й емоційних станів. Звукові комплекси реалізують метафоричні значення на рівні тихого й високого звуків, співвідносних із глибиною відповідних емоційних станів: Далекими світами Вночі $і$ по ночах, Горбатими морями Летів додому 
пmax... I пmax сказав до себе, До вітру на крилі: Нам лиш літати небом, А жити на землі (с. 245); В кукурудзинні з-за лиману, Де тихі дині в жовтих снах, Де зайченята плачуть маму I голубим сміється птах... Мене окликнув хтось!... А множество вже стало станом Позаду мене в небесах... I я заплакав над лиманом, Де голубим сміявся птах! (с. 256); Цієї ночі птах кричав У небо відлетіле, Цієї ночі сніг упав - На чорне впало біле... Один лии птах кричав-болів За морем, за горами, I наш різдвяний стіл білів В кутку під рушниками (с. 160).

Спостережуваними $\epsilon$ фрагменти поетичних текстів, у яких орнітонім 3 узагальненим значенням пmax мотивує емоції й почуття людини. На синтаксичному рівні висловлена думка доводиться отожнювальними сегментами, поданими паралельно: I me, $i$ me: як nmax ранковий Раптово випурхне з трави, Як сон переваний раптовий - Мені не йдеш ти голови... I якби, може, не прощзально Ранковий птах злетів 3 трави - Непереквітло і вінчально Мені не йдеш ти з голови (с. 303).

Алегоризація діалогу, що має корінням фольклорні корені надання особистісних рис орнітонімам: - Синичко, синичко, А де твоя спідничка, I ти на морозі Ходиш в босій нозі? - Була на весіллі, Була й на похміллі, Імоя спідничка Там, де й черевички... (с. 246); Поводимо гусочку по воді Недалечко, Та у неї ж очечка голубі Ще й крилечко! Не пірнай нам, гусочко, бо тоді Кого ж будемо бачити на воді? (с. 386); Прилетіли гуси, сіли у воротях, Оті білі гуси в червоних чоботях, В червоних чоботях, в хустинах рябеньких, Зателгали гуси, що я ще маленький (с. 138).

Поліголосся розгортає картину сприйняття довкілля шляхом послідовного відтворення голосів різних птахів ореалу:

Повільне сонце на тумані До проса випливло з води, Де на пташинім щебетанні Тинявся малиновий дим (с. 184).

Оригінальним авторським рішенням є відтворення поліголосся, що має фоновим підгрунтям фемілістичну основу. За нашою інтерпретацією, подібне суголосся створює яскравий ефект іманентності як результат наслідування певного відчуття: Над гаєм грає птичий грай... I вже по-птичому невпинню Телята підняли хвости. I квокчуть кури попідтинню, I квокче сонце і хати (с. 150).

Наслідування стану, співвідносного з голосовим кваліфікатором в поетичній картині світу Миколи Вінграновського розширює межі феміністичної структури (родоводу), чим досягається ефект інтимізації мовлення: Почапали каченята та по чаполоті, каченята-чапенята: сухо нам у роті... Свого дядька ми приспали, і тата, і маму, діда- 
качура поклали спати в красноталу. А самі, хоч далеченько, чап по чаполоті до води, до водчченьки - сухо ж нам у роті! (с. 266); Лягають спати горобці Із горобчихами та дітьми... (с. 280).

Для поетичного мовлення Миколи Вінграновського характерним $є$ створення ефекту поліголосся шляхом використання множини орнітоніма, збірного поняття, наведення ряду орнітонімів, відтворення значного за обсягом відтинку часу, під час якого триває певний голос; наведення іманентної ознаки певного об' єкта: I стала глибша і свіжіша Качачо-гусяча ріка... (с. 350); Отакого літа ми не мали, Ластівки дітей собі вже мали, вище вікон вигналися мальви, Розсміявся на городі мак, I до тиші доспівався шпак! (с. 252); Над Чернівиями вороняччя, Над Чернівиями голуби... I сміх, $і$ шепіт серию милий, Гуиулки погляд чорнокрилий, Як птича тінь, небесна тінь! (с. 77); В зіницях просторінь безмежна, як світ у птиці під крилом, I - качка дика, обережна - Нога гуиулки під столом... (с. 77); Зіходить ніч на витишений сад... Глибокий вересень шумить крилом качиним... (с. 120).

Поліголосся створює музикальний ефект шляхом використання множини орнітонімів, розширюються межі звукового сприймання довкілля: У білій лодї тоді ми пливемо По водах любощзів між берегами ночі: I голоси у гніздах ластівочі Стихають тихо (с. 194); Качки летять! Марієчко!, - качки... Качки летять! У крилах свище небо... Маріє, мріє, мрієчко моя, Моя Марієчко тривожна, Твоӥм гірким, як світ, ім'ям Мені звучить хвилина кожна (с. 195); Наӥлися шпаки снігу - співать перестали... Заплакали шпаки журно, знялись за туманом, Прилетіли весну стріти - прилетіли рано (с. 220); Вечірньосиньогусто ластівкам (с. 346); Окреслилась ти на вечірнім тлі Отих небес вечірніх з ластівками (с. 94).

Використовуваним є поліголосне поєднання фітонім - зоонім, чим досягається ефект диференційно-вибіркового сприйняття довкілля за слуховим кваліфікатором. Зауважимо, що якщо звук зооніма є визначеним, фіксованим, очікуваним, то звук фітоніма відпочатку співвідносить із шелестом, меншою мірою - наслідуванням звуків, що відбуваються в оточенні фітонімів: І ми самі на самоті... I дощ цілує опівночі Кульбаби очі золоті. Десь кінь ірже - його не чути, Десь хтось іде - його не знать... (с. 262); Пришерхла тиша - сіра миша - У жовто-білих комишах, I попелясто від кошар Вівці копитще землю пише... I сизий цуап - іранський шах - Пришерхлу тишу тихо лиже (с. 263); Сірий глід з гніздом сорочим, Срібне слово павутини! (с. 318); Лии сонях спав, хоча й не мусив, І ось за 
те, аби він знав, Важкий ячмінь медовим вусом Бджслу за лапку лоскотав (с. 184); У срібне царство цчвіркунів Од вітру голубого Упав інжер і розімлів, I не сказав нічого.... Цар цвіркунів Цвіркун-Співець Інжира як побачив, То так зрадів... Що аж зайшовся плачем. За Цвіркуном - у плач оса осиною сльозою. $A$ за осою $i$ роса Сльозою росяною... Утрьох так плакали вони Від радості і щзастя... (с. 219); Hiде нікого. Будякові очі Важкими бджолами, вмираючи, гудуть, Татарський кінь стриже вухами ночі, I місячні серпи ті ночі в копи жнуть (с. 189); I сонним сіном в лузі з будяками, Де, мов живі, до ранку йшли кущі. То кіньми, то людьми, то знову кіньми, А то дивами темними... А то немов чорти чи відьми Нявкали котом. А світ - не нявкав (с. 94); I сірим стовпчиком посвистує ховрах Попід сорочі гнізда у иипиині (с. 259).

Митець послуговується також використанням виключно фітонімічних звукових комплексів, що співвідноситься, як уже наголошувалося, із шелестом (меншою мірою - ляскотінням, глухим звуком падання), а також, за нашим переконанням, метафоричним привнесенням уявного звука, властивого фітоніму, навіяного почуттям або асоціацією: Попідтинню лопух лопотить,...Ледь тріпочуться сині хати В матіольному синьому неводі (с. 178); 3 шовковиць лист, $з$ шовковиць лист учора Упав тихенько, вухо опустив... Нащо тобі треба В иңю ніжну мить турботи ти ї̈, Свою любистком вистелену землю?... I темний сад, вгорнувии неба звии, Схилявся б мовчки в темні чорнобривці... (с. 70); Стручки акації тремтять на пересядку... (с. 260); Додому всі, хто є: стручок квасолі луснув I лусканням свойм всіх наніч налякав (с. 346); Я покажу вам сливи на сучках, Що настромились, падаючи мовчки (с. 183); Серпень ліг під кущем смородини, Шепотів: дозрівай, будь ласка (с. 56); Подалися тополі $в$ тіні, Прив'язалися до села... Прителющать дощі осінні... (с. 56).

Спостережуваним $є$ функціональний ряд із монозвуком, відтворюваним безпосередньо певним птахом. Відтворення такого ряду вимагає фонових знань носія культури: Так цее було спочатку: ніч $і$ сойки в плавнях...(с. 164); 3 будяками тихо привіталася Малинова молодість моя. Добрий день, - сказав сьогодні вечір... I завдала ластівка на плечі Хліб $і$ сіль, i літо, і тепло (с. 299); ... 3 боліт бугай біду мені реве. Я не про те... Я здумав про зозулю. Про місящьь, і про тишу, і про сонь...(с. 186).

Водночас спостерігаємо метафоричне перенесення на рівні орнітонім - людина, що дозволяє глибше і точніше передати відчуття людини: Де я зигзичила за князем, за тобою. I голос мій згорів, 
Кружлялося над пусткою німою... Я плачу: людство, де ти? Мовчу... На грудях космосу я плачу $і$ лечу (с. 134); Я сам самую. Перекигичу... Німію (c. 286). Звук асоціюється із чеканням дорогого, сакрального. Поданий далі ряд нанизувань стягує під один знаменник те, що для поета є рівноцінним.

Спостереваним є перенесення природне явище - фітонім, створюючи ефект всеохопності описуваного явища: ... I правиці репаногарячі Козаків над Лугом у віки. Вони ідуть мені в обличчя... Де воля волю тихо кличе, Де море стогне $і$ кигиче... (с. 168).

Спостерігаємо естетичний ефект, створюваний використанням квазізвуку, що досягається асоціативним співвіднесенням або вірогідним звуком: У лісі вже нічого не иявіте, Цвіте лиш дятел на сосні сумливій Та синій дзвоник уві млі у мливій, Це те иявітіння, але вже не те... (с. 292); Нога трави в багряне відійшла, ззозулена зоря останню росу гонить, Ніхто вже не чека... бо ие тобі боронить Качаточко шустінням в комишах (с. 292).

Використовуваним є прийом поєднання звуків на рівні зоонім природне явище, чим досягається ефект суголосся під час опису поетом картин природи: Лягла зима, $i$ білі солов'ї Затьохкали холодними вустами... Сорока з глоду водить в небо оком, I вітер пише вітрові листа, Сорочим оком пише білобоко. Що гай з землі дивився і стояв, Що солов'ї маліли, як марельки (с. 297).

Оригінальним уявляється комбінований звуковий образ, створюваний шляхом послідовного нанизування звуків довкілля, орнітонімів та зоонімів: Цю грозу не забуду ніколи: 3 ріг корови стікає в краплинах сонще. Босий батько заганяє качок у комору (с. 182); Бабунин дощ... Пускає бульби на порозі хата. Іде хтось темним садом - заховайсь!... Попискують пташата в його вусі, I в бород дрімають ӥюаки. Одне - сов'яче око, друге - вовче... Прийшов під нашу хату ненароком... 3 ноги на ногу ось переступив, Щось наче хтів було мені сказати, та садом знов почапав у степи (с. 356).

Спостережуваним $є$ звуковий вектор сприймання абстрактного поняття - зокрема - відчуття, почуття - посередництвом звуку. На наше переконання, цим досягається ефект не лише алегоризації, але й калітативний, реалізуючи конотації глибини, щирості, справжності відчуття: I що журилося - не журиться, мовчить. Мовчить печаль, $\boldsymbol{i}$ сум мовчить у сумі. I ти мовчиш. Мовчання, й те мовчить (с. 140).

У наведеному фрагменті калітативність досягається шляхом нанизування подібних станів у різноплановних об'єктів. 
Микола Вінграновський - митець пейзажів. У його відтворенні, камертон душі довкілля розгортає його багатотематичну панораму. У наведеному фрагменті тиша співвідносна із тихими приємними звуками природного явища й фітоніма, стягуючи звукове явище під один знаменник, надаючи нового семантичного відтінку корелятивності (від звуку комиша до звуку зір): Вечір... Як тепло ти німуєш! Лищ очерет навстоячки щуось пише, Навпомацки по шепітній воді I над водою й очеретом тиша Виводить в небо зорі молоді Там час себе по ниточизі тороче... (с. 391).

Тихі звуки поет використовує як естетичну платформу задля передавання глибини станів довкілля, «проживання» природного явища своєї сутності. Привертає увагу спектр тихих звуків за ознаками «гучність», «Глибина», «частотність», «переривчастість», «ясність»: $Я$ думав - сам іду. Дорога, I витребеньочка-ріка... Та ще сорока $з$ Междибога... Та вишнячок... Напташивии за літо гнізд, Відслухав їхню щебетанку Й тепер стояв сумний до сліз... Куривсь під дощиком стіжок, Похнюписвя, мовчав і мок, Лиш сіра яблуня-обнога Гукала гілкою листок. Те голе, те ї̈ гукання Безмовно вітер в хмари ніс, Було благання в нім й прощання... Та ще притишене ридання, Як тому вишнячку, до сліз... (с. 382) - тихе благання, ридання, прощання.

Сині очі бджоли. Сад тихенько зацвів. Сад тихенько зацвів $\boldsymbol{i}$ закліпав, - Сині очі бджоли, Там, де груші жили, Там, де груші жили в білих квітах... Собі хміль колискову плете. I сміється гніздо чорногуза. Сходить лагідний хліб (с. 273); У полі спить зоря під колоском I сонно слуха думу колоскову, I сонна тиша сонним язиком Шепоче саду сиву колискову (с. 183); Дрімає вітру срібна дуда, І дика груиа в сні дичить... (с. 280); Шепоче дощ про тебе у траві, Ріку читає сірими очима...(c. 302) - тиша, співвідносна 3 шелестом, паданням, гупанням, уявним пісенним мотивом.

Тиша постає в поетичному просторі Миколи Вінграновського як багатоголосне явище, що розгортає широкий спектр можливих виявів звуків на рівні фітонім (сад, яворина, трава, очерет) - орнітонім (чорногуз, чапля, ворон, горобечь) - зоонім (корівчина)- людина, стан людини - природне явище (дощик). Фонові знання дозволяють відтворити й доповнити динамічність тихого довкілля, неперервне розгортання подій і явищ: Понад лугом сіра сірячина, I намет мій мокриво сумне, Кропить дощик в лузі корівчину, Чорногуза, чаплю $\boldsymbol{i}$ мене. I ніхто не йде, не проминає... Лище дощик, дощик без упину 
Кропить в лузі темну корівчину, Чорногуза, чаплю $i$ мене (с. 390); ...Зимовий сад під вороном білів, Стояли очі у вікні сухому. Смеркалося... Життя лежало тихо, як посів (с. 304); I хтось питає тихо: земле, спиш? Питає тихо Спочила тихо. Сплять горобці, $і$ гори, i трава...і мовкнули гаї. Дай води з криниці... (с. 70); Між очеретом зорі під Десною... Я обнімаю слово. Відлітає До тисячі іще маленька тиш (с. 312); Тихо в моїм серизі і щзасливо... Хлюпочеться плавба... Тіні сплять і сонна яворина... Спить хай Украйна. Капле сон (с. 166).

Образ Любові для Миколи Вінграновського передається емоційними рядками, що відтворюють не короткочасні враження, а глибокі переживання, використовуючи задля цього внутрішні резерви образної палітри. Зокрема, у наведених поетичних рядках стан людини накладається на стан довкілля за звуковими характеристиками «дзвінкість», «частотність»: Забриніло - $і$ незчувсь, як відбриніло I душа вже дзеленчить, як шкло... Й озива овечий мене голос, Мекає Миколою мене. Що воно від ніжності збриніло... (с. 384).

Використовуваним Миколою Вінграновським також є прийом протиставлення на звуковій основі, чим досягається стилістичний ефект широкого діапазону вияву відчуттів за звуковою ознакою «сила звучання». Виявлено протиставлення на таких рівнях:

а) фітонім - орнітонім - людина: Над незаміжньою рікою, Де цвіт, $\boldsymbol{i}$ тиша, й деркачі, Я заспівав тебе сльозою, Твоєю власною вночі (с. 272);

б) фітонім - орнітонім - природне явище: Але було вже пізно мальвам, І літові, і ластівкам, Лиш далечінь синьо благальна Когось благала: не пускай! (с. 307);

в) природне явище - фітонім - орнітонім - людина: I гуркіт молодої зливи, I тьохкіт серця уночі, Солодкий сон оси і сливи, Й сови у присмерку сплачі (с. 379);

г) зоонім - людина: Німію... Як танський фарфор - все минає: Корою, снігом, рукавом... Лише бджсла своє співає Над малиновим будяком (с. 286).

Спостережуваним $\epsilon$ фрагмент поетичного тексту iз протиставленням, у якому наведено перенесення на звуковій основі шляхом їх нанизування. У такий спосіб досягається ефект поліголосся, а також важливості того, що відбувається під час війни, оцінюються іiі наслідки: Ні шелесту, ні диму з димарів, Лии свщще вітер черепу $у$ вуха... Шикує смерть - не спіте! - труп по трупу, Ридають коні... Хропуть иаблі, $і$ ядра захропли. Хропе і втома... I хмара ріжеться 
кривавими рогами В безнебнім небі чорними шляхами, I тиша спить, $\boldsymbol{i}$ віти, і вітри. Мазниці густо сплять, і кругло сплять колеса... (с. 188).

Заслуговує на увагу метафоричне перенесення зоонім-фітонім, у якому традиційна іманентна риса фітоніма тихості набуває ознак, характерних для зооніма. У такому разі пейзажна замальовка сприймається на фоні одного виміру звуку: Джммелі спросоння - буи!! лобами Попадали, ревуть в траві. I задзвонили над джммлями Дзвінки-дзвіночки лісові (с. 184).

Микола Вінграновський також удається до фольклорного основи під час відтворення свого внутрішнього стану. Стан ототожнюється 3 піснею, що дозволяє традиційні образи, які не сягають зазвичай належного рівня узагальнення, наповнити глибоким і неповторним змістом: Заспіваю твоє ім'я, Твоє тихе ім'я вишневе... Де горить під зорею мак, І говорить гроза з грозою. Де дніпрова світання повінь, I на ластівці не згаса Молодий вечоровий промінь... Дорогу, тебе заспіваю (с. 357).

Грунтовний аналіз шляхів досягнення звукових ефектів у творчості Миколи Вінграновського дозволяє дійти висновків про те, що процес перцепції художнього твору органічно здатен поєднати протилежні моменти і тенденції. Зокрема, з одного боку, структура i напрям розвитку перцепції запрограмовано в художньому творі, 3 іншого - здійснюється творча діяльність реципієнта, яка так чи інакше видозмінює втілені в художньому творі образи під впливом індивідуального життєвого досвіду особистості, його естетичних ідеалів, світоглядних принципів і певної цілеспрямованості; емоційні стани, які виникають під час момент естетичного сприймання i переживання $€$ глибоко індивідуальними. Звукові кореляти в поетичній тканині шістдесятника розширюють уявлення про звукопис художнього твору, репрезентують нові парадигми авторських нововведень у межах ідіостилю Миколи Вінграновського.

\section{Література}

1. Блудова В. Природа и структура художественного восприятия: Философскоэстетический подход к изучению художественного восприятия и его частные исследования / В. Блудова // Эстетические очерки. - Вып. 4. : [сборник статей] / ред.сост. С. Х. Раппорт. - М. : Музыка, 1977. - С. 114-152.

2. Дзюба І. Читач як естетична проблема у працях Олександра Білецького // І. Дзюба 3 криниці літ: тритомовик. - К. : Обереги: Гелікон, 2001. - (Сер. «Укр. модерна л-ра»). - Т. 2. - С. 544-561.

3. Вінграновський М. Поезії : Вибрані твори : у трьох томах. - Т. 1. - Тернопіль : Богдан, 2004. - $400 \mathrm{c}$. 
4. Органова О. Н. Специфика эстетического восприятия : [учеб. пособие] / О. Н. Органова. - М. : Высш. школа, 1975. - 224 с.

5. Шеллинг Ф.В.Философия искусства / Ф. В. Шеллинг [пер., вст. статья П. С. Попова и М. Ф. Освянникова]. - М. : Мысль, 1966. - 496 с.

Стаття надійшла до редакції 01.11.2012 р. 